\title{
Grammar-Focused Writing Instruction to the Students' Writing Recount Text
}

\author{
Alvio Arisia Safitri ${ }^{1}$, Dwi Sloria Suharti ${ }^{2}$, Asep Suhendar ${ }^{3}$
}

${ }^{1}$ English Education Study Program of Teacher Training and Education Faculty, Universitas Muhammadiyah Tangerang

${ }^{2}$ English Education Study Program of Teacher Training and Education Faculty, Universitas Muhammadiyah Tangerang

${ }^{3}$ English Education Study Program of Teacher Training and Education Faculty, Universitas Muhammadiyah Tangerang

\section{ARTICLE INFO}

\section{Keywords: Grammar}

Focused Writing

Instruction

Writing Recount Text

\begin{abstract}
In learning English, the students often make some problems while building a recount text. One of the problems causing it is that the teacher might use the old teaching method. This research aimed to examine the effect of grammar-focused writing instruction on the tenth-grade students' writing recount text at one of the Senior High School State at Kabupaten Tangerang. The research method used in this research was a quantitative method with a quasi-experimental design by using a non-equivalent control group design. The population of this research was 460 tenth grade students. The sample of this research was taken from two classes that were chosen by using Simple Random Sampling. There were X IPS 4 as the control class and X IPS 5 as the experimental class. The normality test result showed that the data is normally distributed, and the homogeneity test result showed that the variants belong to a homogeneous population. The analysis results of post-test by using t-test (The Pooled Variance Model T-test) were obtained data that $\mathrm{t}$-count $=4,37$ and $\mathrm{t}$-table $=1,99$ with significant level $a=5 \%$ or 0,05 . From the post-test calculation result, $\mathrm{H} 0$ is rejected, and $\mathrm{H} 1$ is accepted. To sum up, there is a significant effect of students' writing recount text between students in the experimental class who were taught by using grammar-focused writing instruction and students in the control class who were taught by using the conventional method.
\end{abstract}

This is an open access article distributed under the terms of the Creative Commons Attribution 4.0 International License, which permits unrestricted use, distribution, and reproduction in any medium, provided the original work is properly cited. (c) 2020 Alvio Arisia Safitri, Dwi Sloria Suharti, Asep Suhendar.

\footnotetext{
${ }^{1}$ Corresponding author's address: English Education Study Program of Teacher Training and Education Faculty, Universitas Muhammadiyah Tangerang, Banten, Indonesia

e-mail: alviosafitri1@gmail.com

2 Corresponding author's address: English Education Study Program of Teacher Training and Education Faculty, Universitas Muhammadiyah Tangerang, Banten, Indonesia

e-mail: dwisloria@umt.ac.id

${ }^{3}$ Corresponding author's address: English Education Study Program of Teacher Training and Education Faculty, Universitas Muhammadiyah Tangerang, Banten, Indonesia

e-mail: asp_suhendar@yahoo.com
} 


\section{INTRODUCTION}

English is one of the world's critical languages because it can be a lingua franca for connecting one country to others. Many countries use it as their second language or foreign language. These positions depend on many factors, such as the country's location, family background of the citizens, respectively. That is why English has different positions in different countries.

There are four primary skills in English. They are reading, writing, listening, and also speaking. Besides those skills, many English aspects cannot be separated into language learning, such as grammar, vocabulary, pronunciation, and many more. It is almost impossible to learn those skills and aspects in the short term. In Indonesia, English is introduced to the students since they were in elementary school or kindergarten until senior high school or maybe in college to master those skills and aspects. Therefore, writing can be an essential skill in learning English, which is needed to be learned; moreover, it is a productive skill.

Writing is a productive skill besides speaking. Nunan (2003) explains that "writing is the process of thinking to invent ideas, thinking about how to express ideas into good writing, and arranging the ideas into statement and paragraph clearly" (Harris, 2014, p. 55). Writing can be a crucial skill in learning English because the writers are expected to build good writing and deliver the contained ideas efficiently to the reader. Writing can be a group of sentences, which is called a paragraph, and also can be a group of paragraphs, which is called a text.

Writing in English is related to the text type. Several text types have to be explained to the students, such as descriptive text, narrative text, recount text, and report text. In this research, the researchers will choose recount text because it contains past tense, which tells about past events to strengthen the students' memories. According to Anderson (1997), "Defines a recount is a piece of text retells past events, usually in the order in which they happened" (Utami, 2012, p. 25).

According to Cigdem (1997), grammar-focused writing instruction is a teaching method that can make the students think that grammar is essential to be learned, especially in writing. Besides, the specific grammar-structured grammar-focused task does not actually involve direct grammar structure development to accomplish the work answer, but rather aims to draw students' interest to grammar features and increase their knowledge of them (Ellis, (2002) in Nassaji and Fotos (2011)). In this research, the researchers tried to combine grammar and meaning to write their recount text.

The researchers considered that grammar-focused writing instruction could be an alternative method for students when writing recount text to achieve their academic success. The researchers took a quasi-experimental research design to determine whether grammar-focused writing instruction can affect students' writing recount text.

Thus, the researchers wanted to identify the problem by the following question "Is there any significant effect of using grammar-focused writing instruction to the students' writing recount text?"

\section{METHODOLOGY}

This research was quantitative research by using a quasi-experiment design where there are experiment and control groups. The design of the research is to call a non-equivalent controlled design. Riadi (2014, p.14) shows the design of the research non-equivalent as follow:

Table 1. Non-equivalent control group

\begin{tabular}{cccc}
\hline Group & Pretest & Treatment & Posttest \\
\hline Experimental & $\mathrm{Ye}_{\mathrm{e}}$ & $\mathrm{X}$ & $\mathrm{Y}_{\mathrm{e}}$ \\
\hline Control & $\mathrm{Y}^{\mathrm{k}}$ & - & $\mathrm{Y}^{\mathrm{k}}$
\end{tabular}

(Riadi, 2014, p.14) 
Where:

Ye: Score of the experimental group on the pretest

Y"e: Score of the experimental group on post-test

$Y^{k}$ : Score of the controlled group on the pretest

$Y^{\prime \prime}$ : Score of the controlled group on post-test

$X$ : Small Group Discussion treatment

Then, the researchers gave a pretest and post-test in both classes. In the first meeting, the researchers gave a writing recount text test to the students. It was called a pretest. After teaching and learning writing recount text with a grammar-focused writing instruction method, the researchers gave test writing recount text for the students. It was called a post-test. The researchers compared students' post-test scores in controlled and experimental classes to see whether students obtained scores before and after the treatment. It is to see the influence of this method on students' writing recount text achievement.

\section{FINDINGS}

This research was conducted in two classes. Class X IPS 5 consisted of 40 students as the experimental class with a grammar-focused writing instruction method in teaching writing recount text. Class X IPS 4 consisted of 40 students as the controlled class in teaching writing recount text without a grammar-focused writing instruction method.

The researchers obtained the result of the students' scores in experimental and controlled class. The researchers held field research to observe the teaching-learning process, and the researchers got the data from the pretest and post-test. The pretest was given before the lesson began, and the post-test was given after treatment.

In this chapter, the researchers compare pretest and post-test achievement to know whether using grammar-focused writing instruction methods or not writing recount text. The score would be calculated and analyzed.

Firstly, the researchers showed the students' score from both experimental and controlled classes.

Table 2. Students' Score in Experimental class

\begin{tabular}{|c|c|c|c|}
\hline \multirow{2}{*}{ No. } & \multirow{2}{*}{ Respondents } & \multicolumn{2}{|c|}{ Score } \\
\hline & & Pretest & Post-test \\
\hline 1. & Student 1 & 65 & 78 \\
\hline 2. & Student 2 & 57 & 77 \\
\hline 3. & Student 3 & 60 & 78 \\
\hline 4. & Student 4 & 30 & 65 \\
\hline 5. & Student 5 & 56 & 77 \\
\hline 6. & Student 6 & 66 & 78 \\
\hline 7. & Student 7 & 57 & 82 \\
\hline 8. & Student 8 & 66 & 80 \\
\hline 9. & Student 9 & 57 & 75 \\
\hline 10. & Student 10 & 55 & 81 \\
\hline 11. & Student 11 & 52 & 77 \\
\hline 12. & Student 12 & 58 & 73 \\
\hline 13. & Student 13 & 68 & 80 \\
\hline 14. & Student 14 & 63 & 90 \\
\hline 15. & Student 15 & 40 & 70 \\
\hline 16. & Student 16 & 59 & 84 \\
\hline 17. & Student 17 & 60 & 83 \\
\hline 18. & Student 18 & 40 & 75 \\
\hline
\end{tabular}




\begin{tabular}{|c|c|c|c|}
\hline 19. & Student 19 & 55 & 83 \\
\hline 20. & Student 20 & 50 & 77 \\
\hline 21. & Student 21 & 63 & 80 \\
\hline 22. & Student 22 & 60 & 78 \\
\hline 23. & Student 23 & 54 & 80 \\
\hline 24. & Student 24 & 60 & 90 \\
\hline 25. & Student 25 & 57 & 81 \\
\hline 26. & Student 26 & 54 & 81 \\
\hline 27. & Student 27 & 57 & 72 \\
\hline 28. & Student 28 & 56 & 79 \\
\hline 29. & Student 29 & 58 & 78 \\
\hline 30. & Student 30 & 60 & 82 \\
\hline 31. & Student 31 & 50 & 76 \\
\hline 32. & Student 32 & 73 & 80 \\
\hline 33. & Student 33 & 60 & 83 \\
\hline 34. & Student 34 & 52 & 85 \\
\hline 35. & Student 35 & 60 & 80 \\
\hline 36. & Student 36 & 62 & 77 \\
\hline 37. & Student 37 & 30 & 65 \\
\hline 38. & Student 38 & 64 & 85 \\
\hline 39. & Student 39 & 62 & 90 \\
\hline 40. & Student 40 & 73 & 82 \\
\hline \multicolumn{2}{|c|}{ TOTAL } & 2279 & 3167 \\
\hline
\end{tabular}

Based on the result of the comparison between the score of pretest and post-test in the experimental class, it could be identified the pretest that the highest score was 73 and the lowest score was 30, and from post-test, the highest score was 65, and the lowest score was 90.

The score of students' writing recount text in pretest was obtained through testing in the essay form. From the data of students' writing recount text of the experimental class obtained score range from 30 to 73 , the average score is 56.79 , the median is 57.97 , the mode is 58.57 , the standard deviation is 9.2, and the variant is 85.47 .

Students' writing recount text in the post-test was obtained through testing in the essay form. From the data of students' writing recount text of the experimental class obtained score range from 65 to 90 , the average score is 79.4, the median is 79.32, the mode is 79.1 , the standard deviation is 5.4 , and the variant is 29.19 .

Table 3. Students' Score in Controlled class

\begin{tabular}{llcc}
\hline \multirow{2}{*}{ No. } & Respondents & \multicolumn{2}{c}{ Score } \\
\cline { 3 - 4 } & & Pretest & Post-test \\
\hline 1. & Student 1 & 65 & 81 \\
\hline 2. & Student 2 & 36 & 68 \\
\hline 3. & Student 3 & 62 & 73 \\
\hline 4. & Student 4 & 56 & 65 \\
\hline 5. & Student 5 & 60 & 71 \\
\hline 6. & Student 6 & 50 & 68 \\
\hline 7. & Student 7 & 61 & 75 \\
\hline 8. & Student 8 & 66 & 78 \\
\hline 9. & Student 9 & 65 & 75 \\
\hline 10. & Student 10 & 61 & 66 \\
\hline
\end{tabular}




\begin{tabular}{|c|c|c|c|}
\hline 11. & Student 11 & 62 & 65 \\
\hline 12. & Student 12 & 50 & 80 \\
\hline 13. & Student 13 & 64 & 80 \\
\hline 14. & Student 14 & 43 & 70 \\
\hline 15. & Student 15 & 73 & 83 \\
\hline 16. & Student 16 & 30 & 68 \\
\hline 17. & Student 17 & 60 & 80 \\
\hline 18. & Student 18 & 43 & 65 \\
\hline 19. & Student 19 & 50 & 70 \\
\hline 20. & Student 20 & 73 & 79 \\
\hline 21. & Student 21 & 66 & 79 \\
\hline 22. & Student 22 & 43 & 75 \\
\hline 23. & Student 23 & 62 & 78 \\
\hline 24. & Student 24 & 57 & 80 \\
\hline 25. & Student 25 & 68 & 80 \\
\hline 26. & Student 26 & 66 & 78 \\
\hline 27. & Student 27 & 66 & 78 \\
\hline 28. & Student 28 & 57 & 70 \\
\hline 29. & Student 29 & 60 & 80 \\
\hline 30. & Student 30 & 69 & 83 \\
\hline 31. & Student 31 & 62 & 76 \\
\hline 32. & Student 32 & 64 & 78 \\
\hline 33. & Student 33 & 63 & 80 \\
\hline 34. & Student 34 & 60 & 70 \\
\hline 35. & Student 35 & 63 & 75 \\
\hline 36. & Student 36 & 56 & 67 \\
\hline 37. & Student 37 & 70 & 70 \\
\hline 38. & Student 38 & 72 & 75 \\
\hline 39. & Student 39 & 71 & 68 \\
\hline \multirow[t]{2}{*}{40.} & Student 40 & 72 & 78 \\
\hline & TOTAL & 2397 & 2978 \\
\hline
\end{tabular}

Based on the result of the comparison between the score of pretest and post-test in controlled class, it could be identified the pretest that the highest score was 73 and the lowest score was 30 , and from post-test, the highest score was 65, and the lowest score was 83 .

The score of students' writing recount text in pretest was obtained through testing in the essay form. From the data of students' writing recount text of the controlled class obtained score range from 30 to 73 , the average score is 59.42 , the median is 61.5 , the mode is 62.5 , the standard deviation is 11.0, and the variant is 121.24 .

The score of students' writing recount text in the post-test was obtained through testing in an essay. From the data of students' writing recount text of the controlled class obtained score range from 65 to 83 , the average score is 74.62 , the median is 75.5 , the mode is 68.59 , the standard deviation is 5.62 , and the variant is 31.58 .

In analyzing the data, the researchers used the normality test and homogeneity test, and the researchers used a comparative technique to compare the experimental and controlled class. This technique was useful to prove statistically significant differences between the two variables. There were teaching writing recount text using a grammar-focused writing instruction method and using the conventional method. 
In the normality test, the researchers used Chi-square $\left(\mathrm{X}^{2}\right)$. It was aimed to know whether distribution normal or not. The formulation of Chi-square $\left(X^{2}\right)$ as follows:

$\mathrm{X}^{2}$ count $<\mathrm{X}^{2}$ table data distribution is normal

$X^{2}$ count $>X^{2}$ table data distribution is not normal.

The normality test result of the pretest can be seen from the normality test of both classes' pretest. See the table below:

Table 4. Normality Test of Pretest

\begin{tabular}{cccccc}
\hline Class & $\mathrm{N}$ & $\mathbf{X}^{\mathbf{2}}{ }_{\text {count }}$ & $\mathbf{X}^{\mathbf{2}}{ }_{\text {table }}$ & Criteria & Conclusion \\
\hline Experimental & 40 & 10.88 & 12.6 & $\mathrm{X}^{2}$ count $<\mathrm{X}^{2}$ table & Normal \\
\hline Control & 40 & 9.86 & 12.6 & $\mathrm{X}^{2}$ count $<\mathrm{X}^{2}$ table & Normal \\
\hline
\end{tabular}

From the table Chi-square for $\alpha=0.05$ and $\mathrm{dk}=7-1=6$, it was obtained $\mathrm{X}_{\text {table }}=12.6$. The experimental class's pretest data was normal because of $\mathrm{X}^{2}{ }_{\text {count }}<\mathrm{X}^{2}{ }_{\text {table }}(10.88<12.6)$. The controlled class's pretest data was also normal because of $\mathrm{X}_{\text {count }}^{2}<\mathrm{X}^{2}$ table $(9.86<12.6)$.

Table 5. Normality Test of Post-test

\begin{tabular}{cccccc}
\hline Class & $\mathrm{N}$ & $\mathbf{X}^{\mathbf{2}}{ }_{\text {count }}$ & $\mathbf{X}^{\mathbf{2}}$ table & Criteria & Conclusion \\
\hline Experimental & 40 & 10.32 & 12.6 & $\mathrm{X}^{2}$ count $<\mathrm{X}^{2}$ table & Normal \\
\hline Control & 40 & 12.47 & 12.6 & $\mathrm{X}^{2}$ count $<\mathrm{X}^{2}$ table & Normal \\
\hline
\end{tabular}

From the table Chi-square for $\alpha=0.05$ and $\mathrm{dk}=7-1=6$, it was obtained $\mathrm{X}_{\text {table }}^{2}=12.6$. The posttest data of the experimental class is normal because $X^{2}{ }_{\text {count }}<X^{2}$ table $(10.32<12.6)$, and for the post-test data of the controlled class was also normal because of $X^{2}$ count $<X^{2}$ table $(12.47<12.6)$.

Based on the pretest result, the homogeneity test variant for testing the data obtained is homogenous. The computations of homogeneity use the Fisher formula. The completion of this test can be seen as follow:

Table 6. Homogeneity Test

\begin{tabular}{ccccc}
\hline No. & Data & F-count Value & F-table Value & Remarks \\
\hline 1. & Pretest score & 1.19 & 1.7 & \\
\cline { 1 - 3 } 2. & Post-test score & 0.98 & 1.7 & $\begin{array}{c}\text { Data sample are from a } \\
\text { homogeneous population }\end{array}$ \\
\hline
\end{tabular}

The researchers found the value $\mathrm{F}_{\text {-count }}$ in the pretest, and the post-test was lower than $\mathrm{F}_{\text {-table }}$ from the data above. It was 1.7. It means $\mathrm{F}_{\text {count }}<\mathrm{F}_{\text {table }}(1.19<1.69$ and $0.89<1.69)$. Then, it could be assumed that $\mathrm{H}_{0}$ was accepted, and both groups were homogeneous.

The hypotheses test was purposed to know the effect of writing recount text by using grammarfocused writing instruction method could be accepted or could not be accepted based on the data of students' writing recount text by using grammar-focused writing instruction outcome from the post-test experimental class and controlled class in eleventh-grade students of One of the Senior High School State at Kabupaten Tangerang as the subject of the research.

The pretest was normal and homogenous with the sample $\mathrm{n} 1=\mathrm{n} 2$ so that the test hypotheses would be using t-test polled variance.

In the test on pretest class, the hypothesis is as follows:

$\mathrm{H}_{\mathrm{o}}=$ There is no difference in learning writing recount text using a grammar-focused writing instruction method between the controlled and experimental classes. 
$\mathrm{H}_{1}=$ There is a difference in learning writing recount text using a grammar-focused writing instruction method between the controlled and experimental classes.

By using a significance level of $5 \%$, then the test criteria are:

$\mathrm{t}_{\text {-count }}<t_{\text {-table }}$ so, there is no difference in learning writing recount text by using a grammar-focused writing instruction method between the controlled and experimental classes.

$\mathrm{t}_{- \text {count }}>t_{- \text {table}}$, so there is a difference in learning writing recount text using a grammarfocused writing instruction method between the controlled and experimental classes.

From the calculation be found the following data as follows:

Table 7. Hypotheses Test Result

\begin{tabular}{cccc}
\hline No. & Data & $\boldsymbol{t}$-count value & $\boldsymbol{t}$-table Value \\
\hline 1. & Pretest score & -1.08 & 1.99 \\
\hline 2. & Post-test score & 4.37 & 1.99 \\
\hline
\end{tabular}

The pretest analysis results using the T-test (The Pooled Variance Model T-test) were obtained data that $t_{\text {-count }}=-1.08$ and $t$-table $=1.99$ with significant level $a=5 \%$ or 0.05 . From the calculation result, if $t$ count $(-1.08)<t_{\text {table }}(1.99)$, then $\mathrm{H}_{0}$ is accepted. There is no significant difference in the students' writing recount text between the students in the experimental class who were taught by using grammar-focused writing instruction and the students in the controlled class who were taught by the conventional method.

The post-test analysis results using the T-test (The Pooled Variance Model T-test) were obtained data that $t_{\text {-count }}=4.37$ and $t$-able $=1.99$ with significant level $\mathrm{a}=5 \%$ or 0.05 . From the calculation result, if $t$ count $(4.37)>t$-table $(1.99)$, then $\mathrm{H}_{1}$ is accepted. There is no significant difference in the students' writing recount text between the students in the experimental class who were taught by using grammar-focused writing instruction and the students in the controlled class who were taught by the conventional method.

In this research, the researchers used grammar-focused writing instruction to teach writing recount text. Grammar-focused writing instruction effectively improved students' writing recount text and made them more interested in learning English.

Based on the explanation above, the researchers concluded a significant effect using grammarfocused writing instruction to the students' writing recount text at one of the Senior High School State at Kabupaten Tangerang.

\section{DISCUSSION}

Based on this research result, teaching writing recount text by using grammar-focused writing instruction was sufficient. The result above is also supported by Cigdem's (1997) theory. Grammar-focused writing instruction is a teaching method of writing that can make the students think that grammar is essential to be learned, especially in writing. Teaching writing recount text using a grammar-focused writing instruction method in the experimental class got a better score than a controlled class taught by the conventional method.

Another research used writing recount text as Aulia Rizky Ramdhani (2017), this research was focused on the effect of collaborative writing strategy on students' achievement in writing recount text. The result indicates that the alternative hypothesis (Ha) was accepted based on the research data analysis. It means that there is a significant effect of using a Collaborative writing strategy on student achievement in writing recount text. The research conducted by Aulia Rizky Ramadhani 
had the same result as this research that significantly affected each teaching method of writing recount text.

Also, the result of this research was supported by a theory by Hyland (2002), who stated that "Writing is central to our personal experience and social identities and we are often evaluated by our control of it" (Adam, 2015, p. 3). By writing a recount text consisting of personal experience, the students could develop their writing ability because they had to write their own experiences. It also could help the students to strengthen their memory by telling their experience chronologically.

\section{CONCLUSION}

Based on the research finding, it could be concluded that the use of mar focused writing instruction to the students' writing recount text was effective. The obtained score of the t-test proved it. The $t$-test showed that $t_{\text {-count }} 4.37$ was higher than $t_{\text {-table }} 1.99$. It means that $\mathrm{H}_{1}$ was accepted, and Ho was rejected. Therefore, the $t_{\text {-count }}$ was higher than the $t_{\text {-table }}$. There was no significant difference in the achievement between students in class X IPS 5 who were taught using grammar-focused writing instruction and students in class X IPS 4 who were taught without using grammar-focused writing instruction.

\section{REFERENCES}

Adam, S. (2015). A Study on Students' Ability in Writing Recount Text. Universitas Negeri Gorontalo.

Cigdem, M. (1997). The Effects of Grammar-Focused Writing Instruction on the Writing Abilities of Students at the University of Gaziosmanpasa in Tokat. Bilkent University.

Harris, A., Ansyar, M., \& Radjab, D. (2014). An Analysis of Students' Difficulties in Writing Recount Text at Tenth Grade of SMAN 1 Sungai Limau. Journal of English Language Teaching (ELT).

Nassaji, H., \& Fotos, S. (2011). Teaching Grammar in Second Language Classroom. New York: Routledge.

Ramadhani, A. R. (2017). The Effect of Collaborative Writing Strategy on Students' Achievement in Writing Recount Text in MTS Alwashliyah Tembung 2016/2017. University of North Sumatera Medan.

Riadi, E. (2014). Metode Statistika Prametrik \& Nonparametrik: untuk peneliian ilmu-ilmu sosial dan pendidikan. Tangerang: Pustaka Mandiri.

Utami, D., Sani, R. D., \& Pratiwi, A. (2018). The Effect of Teaching Diary in Recount Text (at SMAN 10 Mukomuko in Academic Year 2017/2018). STKIP PGRI Sumatera Barat. 